\section{Foliar Application of Zinc and Boron Improves Walnut Vegetative and Reproductive Growth}

\author{
Karim Keshavarz ${ }^{1}$, Kourosh Vahdati ${ }^{1,5}$, Mahmoud Samar $^{2}$, \\ Behzad Azadegan ${ }^{3}$, and Patrick H. Brown ${ }^{4}$
}

AdDitional INDEX wORDs. Juglans regia, Zn, B, spray, fruit set, pollen germination, kernel percent

SUMMARY. An experiment was conducted in a persian walnut (Juglans regia) orchard in the north of Iran to evaluate the effects of zinc $(\mathrm{Zn})$ as zinc sulfate and/or boron (B) as boric acid in foliar spray with different concentrations and combinations. Three $B$ and three $\mathrm{Zn}$ concentrations $\left(0,174\right.$, and $348 \mathrm{mg} \cdot \mathrm{L}^{-1}$ for $\mathrm{B}$ and 0,1050 , and $1750 \mathrm{mg} \cdot \mathrm{L}^{-1}$ for $\mathrm{Zn}$ ) were applied either independently or in combination. Leaf nutrient concentrations, pollen germination, fruit set, leaf chlorophyll index, nut and kernel characteristics, vegetative growth, nut weight, and nut yield were measured to assess the effects of treatments. The results showed that all $\mathrm{B}$ and $\mathrm{Zn}$ applications and combinations had a significant effect on all traits except nut and kernel diameter, shell percent, husk thickness, and pistillate flower abscission (PFA). Pollen germination, fruit set, vegetative growth, nut weight, kernel percent, nut and kernel length, and chlorophyll index were highest when $B$ and $\mathrm{Zn}$ were applied simultaneously at 174 and $1050 \mathrm{mg} \cdot \mathrm{L}^{-1}$ concentrations, respectively.

$\mathrm{P}$ ersian walnut is sensitive to $\mathrm{B}$ and $\mathrm{Zn}$ deficiency (Ramos, 1997), especially in sandy soils with low organic matter and also in calcareous soils (Storey, 2007). These conditions are predominant in many walnut orchards around the world, particularly in Iran (Momeni, 2003; Ziaeian and Malakouti, 2001). Boron and $\mathrm{Zn}$ deficiencies are more probable early in the season because the translocation of elements from the root to the aboveground portion may not be adequate before leaf expansion (Neilsen et al., 2004). Zinc and B have a critical effect on flowering and fruit set and for this reason spring foliar application of these elements are frequently recommended in walnut orchards. In soils with a strong $\mathrm{Zn}$ fixation capacity, spring foliar fertilization has several advantages

We thank the University of Tehran and Iran National Science Foundation for financial supports of this research. Also, we greatly appreciate the help of $\mathrm{Mr}$. M. Momeni (Manager of the Shahmirzad Kesht va Sanaat Company) for providing plant materials and Soil and Water Research Institute of Iran for laboratory facilities.

${ }^{1}$ Department of Horticulture, College of Abouraihan, University of Tehran, Tehran, Iran

${ }^{2}$ Department of Soil Chemistry, Fertility and Plant Nutrition, Soil and Water Research Institute, Tehran, Iran

${ }^{3}$ Department of Irrigation and Drainage, College of Abouraihan, University of Tehran, Tehran, Iran

${ }^{4}$ Department of Plant Sciences, University of California, Davis, One Shields Avenue, CA 95616

${ }^{5}$ Corresponding author. E-mail: kvahdati@ut.ac.ir. including low application rate, uniform distribution of fertilizer materials, efficacy before leaf development, and quick response (Umer et al., 1999).

Severe B deficiency symptoms in walnut trees consist of long, leafless shoots, mostly in the tops of trees, and flattened and twisted shoots at the tips. These shoots die during the following winter. Moderate B deficiency in walnut results in reduced yields in otherwise healthy looking trees (Ramos, 1997). Boron plays an important role in pollen germination and pollen tube growth (Storey, 2007 ) and foliar sprays of $B$ increase pollen germination in a number of tree species including almond [Prumus amygdalus (Nyomora et al., 1997)], pear [Pyrus communis (Lee et al., 2009)], and meyer spruce [Picea meyeri (Wang et al., 2003)] and fruit set in almond, sweet cherry (Prunus avium), hazelnut (Corylus avellana), and apple (Malus $\times$ domestica) (Nyomora et al., 1997; Shrestha et al., 1987; Silva et al., 2003; Usenik and Stampar, 2002; Wojcik and Treder, 2006).

Zinc is a cofactor of over 300 enzymes and proteins and has an early and specific effect on cell division, nucleic acid metabolism, and protein synthesis (Marschner, 1986). In many deciduous species, $\mathrm{Zn}$ deficiency can have a marked effect on pollen production, pollen physiology, floral anatomy, and yield (Usenik and Stampar, 2002; Ute and Clemens, 2005). Zinc deficiency in walnut is visually expressed as small leaves and nuts, delayed opening of vegetative and flower buds, leaf chlorosis between the lateral veins, wavy leaves with upward folded leaf margins and terminal dieback (Ramos, 1997). Foliar applications of $\mathrm{Zn}$ have been successfully used to promote tree vigor, fruit set, and yield in apple (Wojcik, 2007) and 'Washington Navel' orange (Citrus sinensis) (Hafez and El-Metwally, 2007). Brown et al. (1995a) stated that applications of foliar $\mathrm{Zn}$ to mature leaves were ineffective and did not provide significant $\mathrm{Zn}$ to new leaves developed after spray application or in the subsequent spring. The best time for $\mathrm{Zn}$ foliar application was found to be immediately after pistillate flower senescence and for the 2 weeks subsequently (Brown et al., 1995a). Both $\mathrm{Zn}$ and $\mathrm{B}$ applications have been observed to have a positive effect on chlorophyll contents in B- and $\mathrm{Zn}$-deficient plants

\begin{tabular}{llll}
\hline $\begin{array}{l}\text { Units } \\
\text { To convert U.S. to SI, } \\
\text { multiply by }\end{array}$ & U.S. unit & SI unit & $\begin{array}{l}\text { To convert SI to U.S., } \\
\text { multiply by }\end{array}$ \\
\hline 0.4047 & $\mathrm{acre}(\mathrm{s})$ & $\mathrm{ha}$ & 2.4711 \\
0.3048 & $\mathrm{ft}$ & $\mathrm{m}$ & 3.2808 \\
0.0283 & $\mathrm{ft}^{3}$ & $\mathrm{~m}^{3}$ & 35.3147 \\
0.0700 & $\mathrm{ft}^{3} / \mathrm{acre}$ & $\mathrm{m}^{3} \cdot \mathrm{ha}^{-1}$ & 14.2913 \\
3.7854 & $\mathrm{gal}$ & $\mathrm{L}$ & 0.2642 \\
9.3540 & $\mathrm{gal} / \mathrm{acre}$ & $\mathrm{L} \cdot \mathrm{ha}^{-1}$ & 0.1069 \\
2.54 & inch $(\mathrm{es})$ & $\mathrm{cm}$ & 0.3937 \\
25.4 & inch $(\mathrm{es})$ & $\mathrm{mm}$ & 0.0394 \\
0.4536 & $\mathrm{lb}$ & $\mathrm{kg}$ & 2.2046 \\
1.1209 & $\mathrm{lb} / \mathrm{acre}$ & $\mathrm{kg} \cdot \mathrm{ha}^{-1}$ & 0.8922 \\
1 & $\mathrm{mmho} / \mathrm{cm}$ & $\mathrm{dS} \cdot \mathrm{m}^{-1}$ & 1 \\
28.3495 & $\mathrm{oz}$ & $\mathrm{g}$ & 0.0353 \\
1 & $\mathrm{ppm}$ & $\mathrm{mg} \cdot \mathrm{kg}^{-1}$ & 1 \\
1 & $\mathrm{ppm}$ & $\mathrm{mg} \cdot \mathrm{L}^{-1}$ & 1 \\
$\left({ }^{\circ} \mathrm{F}-32\right) \div 1.8$ & ${ }^{\circ} \mathrm{F}$ & ${ }^{\circ} \mathrm{C}$ & $\left(1.8 \times{ }^{\circ} \mathrm{C}\right)+32$ \\
& & &
\end{tabular}


(Kaya and Higgs, 2002; Zheng et al., 1989). Foliar B and $\mathrm{Zn}$ have both been observed to increase vegetative growth in mango (Mangifera indica) when trees were sprayed with 800 $\mathrm{mg} \cdot \mathrm{L}^{-1} \mathrm{Zn}$ (Rajput et al., 1976).

Several studies have emphasized the critical role that concentration of $\mathrm{Zn}$ and $\mathrm{B}$ in the spray solution has on efficacy of the application. Nyomora et al. (1997) showed that foliar application of 245 and $490 \mathrm{mg} \cdot \mathrm{L}^{-1}$ of sodium octaborate (Solubor; U.S. Borax, Greenwood Village, CO) in almond resulted in greater fruit set and yield than either the application of 0 or $735 \mathrm{mg} \cdot \mathrm{L}^{-1}$. Solar and Stampar (2001) reported that yield of hazelnut trees was highest in the treatment with $2000 \mathrm{mg} \cdot \mathrm{kg}^{-1} \mathrm{~B}+2000$ $\mathrm{mg} \cdot \mathrm{L}^{-1} \mathrm{Zn}$ and lowest in the treatment with $1000 \mathrm{mg} \cdot \mathrm{L}^{-1} \mathrm{~B}+1000 \mathrm{mg} \cdot \mathrm{L}^{-1}$ $\mathrm{Zn}$. Silva et al. (2003) stated that the foliar application of 600 and 900 $\mathrm{mg} \cdot \mathrm{L}^{-1}$ of $\mathrm{B}$ increased nut yield of hazelnut more than $300 \mathrm{mg} \cdot \mathrm{L}^{-1}$ treatment.

The possible synergistic effect of combined $\mathrm{Zn}$ and $\mathrm{B}$ applications has been examined in several species. In gladiolus (Gladiolus grandiflorus), height and number of effective leaves per plant were progressively increased by the addition of $\mathrm{B}$ and $\mathrm{Zn}$ up to 2 and $3 \mathrm{~kg} \cdot \mathrm{ha}^{-1}$, respectively, in contrast with the application of each individually. A greater or lower concentration of either element resulted in lower productivity than the combined spray (Memon et al., 2009). Moreover, foliar application of $\mathrm{B}$ and $\mathrm{Zn}$, simultaneously in almond trees, increased fruit set by $38 \%$, whereas when B or $\mathrm{Zn}$ was applied alone, fruit set was $27.7 \%$ and $22.2 \%$, respectively (Sotomayor et al., 2000). Combined foliar application of $\mathrm{Zn}$ and $\mathrm{B}$ on sweet cherry increased fruit set and yield to a greater extent than application of either element alone (Usenik and Stampar, 2002).

Despite many studies on the response of deficient fruit trees to $\mathrm{Zn}$ and B foliar application, there is little knowledge directly relevant to walnut trees. Because of the high cost of labor and application machinery, it is currently a standard practice to combine foliar materials into a single spray. The main objectives of this study were to determine the best concentration and combination of $\mathrm{Zn}$ and $\mathrm{B}$ for application to persian walnut.

\section{Material and methods}

The experiment was conducted from 2007 to 2009 in a 400-ha commercial persian walnut orchard located in Shahmirzad, Semnan Province, Iran (lat. $52^{\circ} 21^{\prime} \mathrm{N}$, long. $35^{\circ} 41^{\prime} \mathrm{W}$ ). The height of trees was $3 \mathrm{~m}$ and crown size was $11.5 \mathrm{~m}^{3}$. The orchard was planted on strongly sloping land ( $8 \%$ grade), and the soil texture was silty loam with pH 7.9, containing about $60 \%$ calcium carbonate and less than $0.8 \%$ organic matter (Table 1). Walnut trees require a soil of fairly neutral $\mathrm{pH}$ between 6.5 and 7.2. In soils with $\mathrm{pH}$ of 7.0 or higher, $\mathrm{Zn}$ and some other micronutrients are held very tightly by the soil and are unavailable for plant uptake. The effect of $\mathrm{pH}$ on $\mathrm{B}$ at these $\mathrm{pH}$ ranges is not well characterized but would generally be expected to be minimal. The plant materials consisted of 10-year-old $\mathrm{Z}_{63}$ domestic walnut seedling of promising genotype spaced $15 \times 15 \mathrm{~m}^{2}$. Trees were drip irrigated using one drip line for each row, with seven emitters per tree, each with a flow rate of $4 \mathrm{~L} \cdot \mathrm{h}^{-1}$. Irrigation was applied from early April until mid December. The volume of irrigation water was about $4000 \mathrm{~m}^{3} \cdot \mathrm{ha}^{-1}$, and trees were irrigated with $16 \mathrm{~m}^{3}$ of water weekly. The experiment was a completely block randomized $3 \times 3$ factorial design with two factors, three $\mathrm{B}$ concentrations $\left(0,174\right.$, and $348 \mathrm{mg} \cdot \mathrm{L}^{-1}$ for $\mathrm{B} 0, \mathrm{~B} 1$, and $\mathrm{B} 2$, respectively) and three $\mathrm{Zn}$ concentrations $(0,1050$, and $1750 \mathrm{mg} \cdot \mathrm{L}^{-1}$ for $\mathrm{Zn} 0, \mathrm{Zn} 1$, and $\mathrm{Zn} 2$, respectively) in four replications (blocks). Boron was applied as boric acid (17.4\% B) and $\mathrm{Zn}$ was applied separately as $\mathrm{Zn}$ sulphate monohydrate ( $35 \% \mathrm{Zn})$ manufactured by Golzar (Tehran, Iran). In $\mathrm{B} 0 \mathrm{Zn} 0$, trees received no foliar-applied $\mathrm{Zn}$ or B. Foliar sprays were performed by means of a handgun sprayer ( 34 $\mathrm{L} \cdot \mathrm{min}^{-1}$ ) using $1000 \mathrm{~L} \cdot \mathrm{ha}^{-1}$. There were 10 trees in each block, and data from 10 trees were averaged and treated as a single replicate, so that 360 trees were tested in total. Trees were visually similar in morphological features such as canopy volume and trunk diameter.

Soil samples were taken from a depth of $0-30$ and $30-60 \mathrm{~cm}$ from the orchard before treatments were applied in Oct. 2007. Soil characteristics are presented in Table 1. All trees were sprayed three times in each season. The first spray was performed at the beginning of fall, 1 week after harvest (20 Sept.). These trees did not lose leaves for at least $30 \mathrm{~d}$ after harvest. The second spray was applied at the beginning of growth when feathers of the pistillate flowers had turned brown in mid-April, and the third spray was applied at the beginning of May (2 weeks later).

Two representative branches were selected from each tree to monitor the total number of flowers and fruits on selected dates throughout 2008 and 2009 seasons. The branches were selected from east and west sides of the canopies and received about equal hours of direct sunlight. Selected branches from each tree were monitored for pistillate flower formation, and the total number of pistillate flowers was counted on 11 May 2007. On 15 July 2007, the number of fruits was counted to estimate the intermediate fruit set (number of nuts/number of initial flowers $\times 100)$. On 12 Sept. 2007, just before harvest, the number of fruits was counted to estimate final fruit set (number of nuts/number of initial flowers $\times 100)$.

Pollen was collected during Spring 2009. Staminate inflorescences having some flowers with dehiscent anthers were brought into the laboratory and pollen shed over the next $2 \mathrm{~h}$ was collected. Pollen were germinated on a medium containing $20 \%(\mathrm{w} / \mathrm{v})$ sucrose, $1.0 \mathrm{~mol} \cdot \mathrm{m}^{-3} \mathrm{cal}-$ cium chloride, $100 \mathrm{~g} \cdot \mathrm{m}^{-3}$ boric acid, and $0.65 \%(\mathrm{w} / \mathrm{v})$ agar (Luza and Polito, 1991). After incubation for $24 \mathrm{~h}$, the plates were sampled randomly and germination percentage was determined for at least 500 pollen grains of each tree.

Pistillate flower abscission was determined by the methods of McGranahan et al. (1994). Nitrogen (N), phosphorus $(\mathrm{P})$, potassium $(\mathrm{K})$, sodium $(\mathrm{Na})$, $\mathrm{Zn}$, iron $(\mathrm{Fe})$, copper $(\mathrm{Cu})$, magnesium $(\mathrm{Mn})$, and $\mathrm{B}$ in leaf tissues were determined $90 \mathrm{~d}$ after flowering. Forty leaflets from middle leaflet pairs of mature leaves on terminal shoots were collected from the mid-third portion of current season growth. Leaf samples were washed with distilled water, dried at $65^{\circ} \mathrm{C}$ for $48 \mathrm{~h}$, ground to pass $1-\mathrm{mm}$ sieve, stored in plastic bags before analyses, and analyzed.

Nitrogen was measured according to Kjeldahl's method (Ostrowska et al., 1991). Phosphorus was determined colorimetrically using the vanado-molybdophosphoric method (Ostrowska et al., 


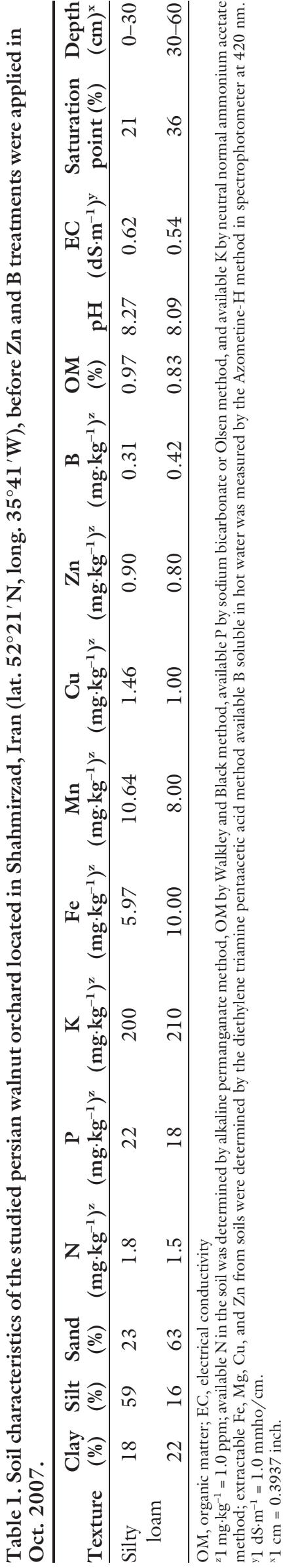

1991). Potassium was determined according to the method of Evenhuis and De Waard (1980). Zinc, Fe, and Mn concentrations wwere determined by atomic absorption spectrometer (Perkin-Elmer, Norwalk, CT). Boron was measured with the curcumin spectrophotometric method (Lieten, 2002).

The initial nutrient status of trees was $2.38 \% \mathrm{~N}, 1.60 \% \mathrm{~K}, 0.17 \% \mathrm{P}, 1.2 \%$ $\mathrm{Ca}, 89.8 \mathrm{mg} \cdot \mathrm{kg}^{-1} \mathrm{Mn}, 118.30 \mathrm{mg} \cdot \mathrm{kg}^{-1}$ $\mathrm{Fe}, 12 \mathrm{mg} \cdot \mathrm{kg}^{-1} \mathrm{Zn}$, and $55 \mathrm{mg} \cdot \mathrm{kg}^{-1} \mathrm{~B}$. All leaf nutrient values are above existing standards, with the exception of $\mathrm{Zn}$ and B (Ramos, 1997). However, it should be noted that the experimental basis for definition of $\mathrm{B}$ and $\mathrm{Zn}$ standards is not known.

Chlorophyll measurements were collected with a hand-held dualwavelength chlorophyll meter (SPAD 502; Minolta, Tokyo, Japan). On each tree, four leaves were sampled from four shoots located at midheight of the canopy in the four cardinal directions (16 values per tree) on 15 July. The mean of these 16 readings was used for all treatment comparisons.

A sample of 30 nuts was collected from each tree at harvest time (23 Sept. 2008 and 10 Sept. 2009) for the determination of nut weight (grams), nut length (centimeters), nut diameter (centimeters), and length/ diameter ratio. Husks and shells were removed manually. Husk thickness was measured by a vernier caliper. Kernel length, kernel diameter, kernel weight, and shell and kernel percent were also determined.

The data were subjected to analysis of variance using SAS (version 9; SAS Institute, Cary, NC), and the differences were compared by using the Duncan's multiple range test at $P \leq 0.05$.

\section{Results}

INFLUENCE OF FOLIAR B APPLICATIONS. The main effect of $B$ was significant as applications of $\mathrm{B}$ at $174 \mathrm{mg} \cdot \mathrm{L}^{-1}$ (Bl) markedly increased yield and quality characteristics (Table 2). Furthermore, the $174 \mathrm{mg} \cdot \mathrm{L}^{-1} \mathrm{~B}$ treatment resulted in higher nut yield compared with other $B$ treatments. For all variables measured, the application of $\mathrm{B}$ at 348 $\mathrm{mg} \cdot \mathrm{L}^{-1}$, although superior to $0 \mathrm{mg} \cdot \mathrm{L}^{-1}$ $B$ applications, was less effective than $174 \mathrm{mg} \cdot \mathrm{L}^{-1} \mathrm{~B}$ application. Boron applied at $174 \mathrm{mg} \cdot \mathrm{L}^{-1}$ also increased pollen germination. There was a significant positive effect of $B$ treatments on chlorophyll, with highest values recorded at $174 \mathrm{mg} \cdot \mathrm{L}^{-1} \mathrm{~B}$ application. Vegetative growth, assessed as current shoot growth, was influenced by $\mathrm{B}$ applications in 2009 and 2008, but on increasing B concentration, vegetative growth decreased compared with $\mathrm{Bl}$. Boron at $174 \mathrm{mg} \cdot \mathrm{L}^{-1}$ was more effective than at $348 \mathrm{mg} \cdot \mathrm{L}^{-1} \mathrm{~B}$ (Table $2)$. Boron applications increased tissue $\mathrm{N}, \mathrm{P}, \mathrm{K}, \mathrm{Zn}, \mathrm{Fe}$, and B (Table 3 ).

INFLUENCE OF FOLIAR $Z_{N}$ APplications. The main effect of $\mathrm{Zn}$ was significant as application of $\mathrm{Zn}$ alone at $1050 \mathrm{mg} \cdot \mathrm{L}^{-1}$ resulted in an increase in yield, nut length, and higher kernel percent compared to 0 or 1750 $\mathrm{mg} \cdot \mathrm{L}^{-1} \mathrm{Zn}$ (Table 2), but in other parameters, $\mathrm{Znl}$ was more effective than $\mathrm{Zn} 0$ and $\mathrm{Zn} 2$, and there was no difference between $\mathrm{Zn} 0$ and $\mathrm{Zn} 2$ (Table 3 ).

INTERACTIVE EFFeCTs. For many of the parameters measured, the combination of $\mathrm{Zn}$ and $\mathrm{B}$ resulted in a greater response than either element supplied individually and was significant (Table 2). The combined applications of $\mathrm{B}$ and $\mathrm{Zn}$ at 174 and 1050 $\mathrm{mg} \cdot \mathrm{L}^{-1}$, respectively, increased walnut yield by $400 \%$ when compared with unsprayed controls (Table 2). While combined $\mathrm{Zn}$ and $\mathrm{B}$ sprays had a positive effect on fruit set in both years, the interaction between $\mathrm{B}$ and $\mathrm{Zn}$ differed between years. In 2008, the highest fruit set was obtained from 174 and $1050 \mathrm{mg} \cdot \mathrm{L}^{-1}$ concentration of $\mathrm{B}$ and $\mathrm{Zn}$, respectively, while in 2009 , the highest fruit set was obtained with $174 \mathrm{mg} \cdot \mathrm{L}^{-1} \mathrm{~B}$ and 1050 $\mathrm{mg} \cdot \mathrm{L}^{-1} \mathrm{Zn}$ and $174 \mathrm{mg} \cdot \mathrm{L}^{-1} \mathrm{~B}$ and $1750 \mathrm{mg} \cdot \mathrm{L}^{-1} \mathrm{Zn}$ (Table 2). Foliar Zn applications were effective only in promoting pollen germination when applied at $1050 \mathrm{mg} \cdot \mathrm{L}^{-1}$ in combination with $174 \mathrm{mg} \cdot \mathrm{L}^{-1} \mathrm{~B}$. Chlorophyll index was the highest at 1050 and $174 \mathrm{mg} \cdot \mathrm{L}^{-1} \mathrm{Zn}$ and $\mathrm{B}$, respectively (Table 2). In 2008, $174 \mathrm{mg} \cdot \mathrm{L}^{-1} \mathrm{~B}+$ $1050 \mathrm{mg} \cdot \mathrm{L}^{-1} \mathrm{Zn}$ and $174 \mathrm{mg} \cdot \mathrm{L}^{-1} \mathrm{~B}+$ $1750 \mathrm{mg} \cdot \mathrm{L}^{-1} \mathrm{Zn}$ and, in 2009,174 $\mathrm{mg} \cdot \mathrm{L}^{-1} \mathrm{~B}+1050 \mathrm{mg} \cdot \mathrm{L}^{-1}$ of $\mathrm{Zn}$ resulted in the longest new shoot length (Table 2 ). Leaf analysis showed that the highest concentration of $\mathrm{N}$ was achieved with application of $174 \mathrm{mg} \cdot \mathrm{L}^{-1} \mathrm{~B}+$ $1750 \mathrm{mg} \cdot \mathrm{L}^{-1} \mathrm{Zn}$, while the lowest $\mathrm{N}$ concentration was obtained in the control treatment when neither treatment was applied (Table 3 ).

All yield and quality parameters except nut and kernel diameter, shell 


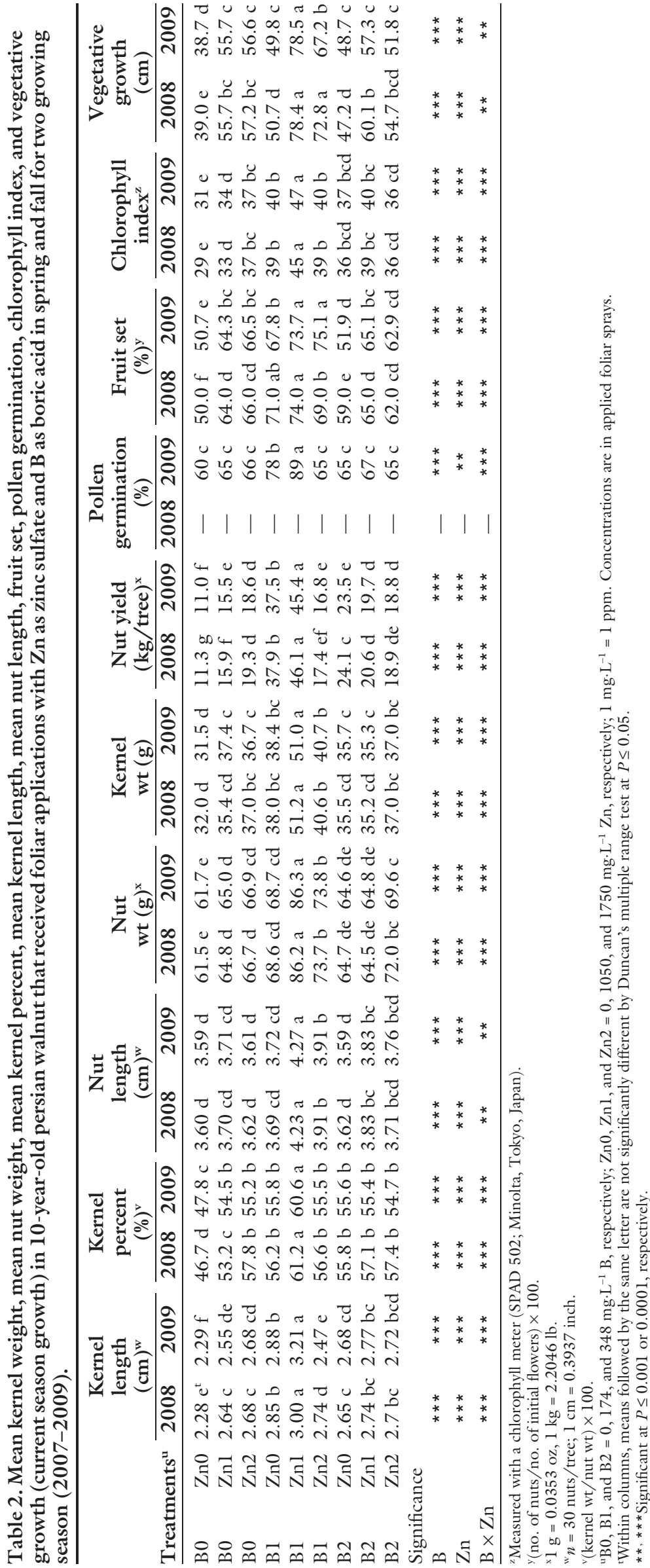

percent, and husk thickness were increased by foliar application of $\mathrm{Zn}$, $\mathrm{B}$, or both, with the highest values consistently achieved by application of $174 \mathrm{mg} \cdot \mathrm{L}^{-1} \mathrm{~B}$ and $1050 \mathrm{mg} \cdot \mathrm{L}^{-1} \mathrm{Zn}$ simultaneously. Applications of B at $174 \mathrm{mg} \cdot \mathrm{L}^{-1}$ markedly increased yield and quality characteristics, while the simultaneous application of $1050 \mathrm{mg} \cdot \mathrm{L}^{-1}$ $\mathrm{Zn}$ further enhanced yield. Application of $\mathrm{Zn}$ alone at $1050 \mathrm{mg} \cdot \mathrm{L}^{-1}$ resulted in a small but still significant increase in yields and nut size. Application of $\mathrm{B}$ at $348 \mathrm{mg} \cdot \mathrm{L}^{-1}$, although superior to $0 \mathrm{mg} \cdot \mathrm{L}^{-1} \mathrm{~B}$ application, was always less effective than $174 \mathrm{mg} \cdot \mathrm{L}^{-1} \mathrm{~B}$ application.

Although combined $\mathrm{Zn}$ and $\mathrm{B}$ sprays had a positive effect on fruit set in both years, the interaction between $\mathrm{B}$ and $\mathrm{Zn}$ differed between years. In 2008 , the highest fruit set was obtained from 174 and $1050 \mathrm{mg} \cdot \mathrm{L}^{-1} \mathrm{con}-$ centration of $\mathrm{B}$ and $\mathrm{Zn}$, respectively, while in 2009, the highest fruit set was obtained with $174 \mathrm{mg} \cdot \mathrm{L}^{-1} \mathrm{~B}$ and $1050 \mathrm{mg} \cdot \mathrm{L}^{-1} \mathrm{Zn}$ and $174 \mathrm{mg} \cdot \mathrm{L}^{-1} \mathrm{~B}$ and $1750 \mathrm{mg} \cdot \mathrm{L}^{-1} \mathrm{Zn}$ (Table 2).

\section{Discussion}

The value of spring foliar $B$ and $\mathrm{Zn}$ for fruit set and yield has been demonstrated in many fruit and nut trees (Neilsen et al., 2004) and has been reported in nonrefereed publications for walnut grown in California (Brown et al., 1999; Ramos, 1997). Here, we demonstrate a clear positive effect of $\mathrm{B}$ and $\mathrm{Zn}$ applied as individual spray applications and a synergistic effect of these elements when applied in combination on walnut yield and quality parameters. For most parameters measured here, optimal response to foliar $\mathrm{Zn}$ occurred at $1050 \mathrm{mg} \cdot \mathrm{L}^{-1}$ $\mathrm{Zn}$ and was enhanced by the coapplication of B at $174 \mathrm{mg} \cdot \mathrm{L}^{-1}$

To our knowledge, this is the first report of the benefit of foliar B and $\mathrm{Zn}$ on pollen germination in walnut trees. Our results in walnut are in general concurrence with those of Nyomora et al. (1997) in almond, who reported that the highest pollen germination and fruit set were observed when B was sprayed at 490 $\mathrm{mg} \cdot \mathrm{L}^{-1}$ in 1993 and $735 \mathrm{mg} \cdot \mathrm{L}^{-1}$ in 1994 in 'Butte'. Lee et al. (2009) reported the highest in vitro pollen germination in pear was achieved at 100 and $300 \mathrm{mg} \cdot \mathrm{kg}^{-1} \mathrm{~B}$, and in field trials in pear (Lee et al., 2009), 200 $\mathrm{mg} \cdot \mathrm{L}^{-1} \quad \mathrm{~B}$ resulted in the highest 
Table 3. Effects of $\mathrm{Zn}$ as zinc sulfate and $\mathrm{B}$ as boric acid treatment applied in spring and fall in two growing season on leaf nutrient concentration in 10-year-old persian walnut trees. Leaf samples were washed with distilled water, dried at $65{ }^{\circ} \mathrm{C}$ $\left(149.0^{\circ} \mathrm{F}\right)$ for $48 \mathrm{~h}$, ground to pass through $1-\mathrm{mm}(0.04 \mathrm{inch})$ sieve. $\mathrm{N}$ was measured according to Kjeldahl's method, $P$ by vanado-molybdo-phosphoric method, $\mathrm{K}$ by Evenhuis and De Waard method, $\mathrm{Zn}$ and $\mathrm{Fe}$ by atomic absorption spectrometer; and B by curcumin spectrophotometer.

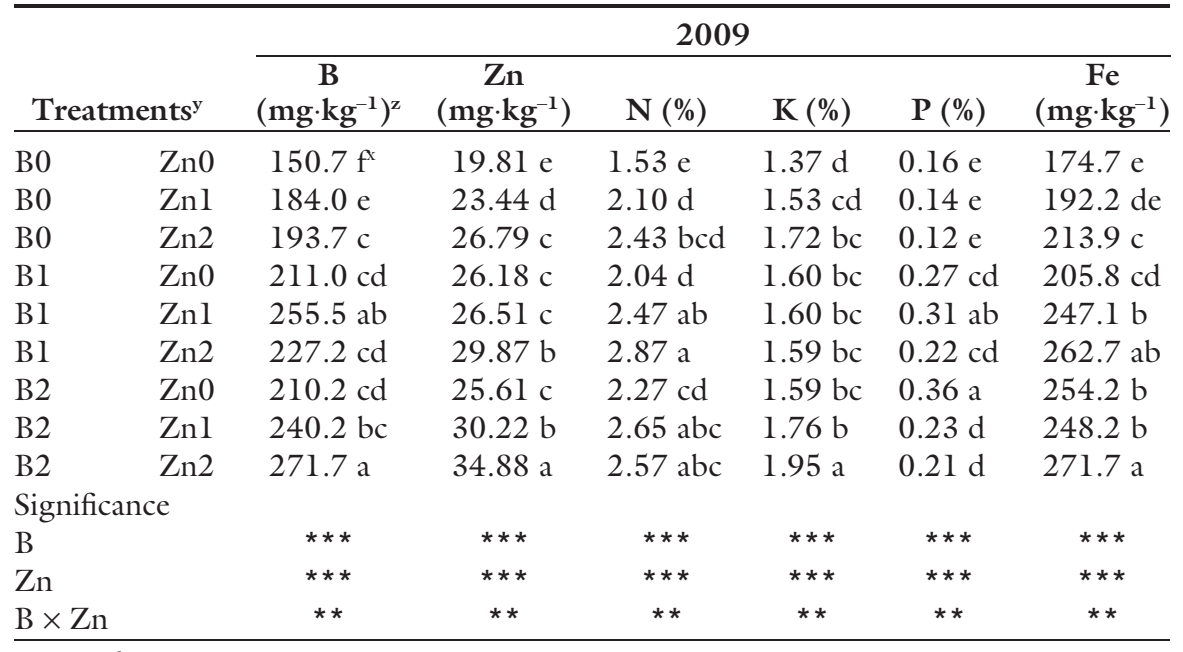

${ }^{\mathrm{z}} \mathrm{l} \mathrm{mg} \cdot \mathrm{kg}^{-1}=1 \mathrm{ppm}$.

${ }_{\mathrm{B}}^{\mathrm{B} 0}, \mathrm{Bl}$, and $\mathrm{B} 2=0,174$, and $348 \mathrm{mg} \cdot \mathrm{L}^{-1} \mathrm{~B}$, respectively; $\mathrm{Zn0}, \mathrm{Znl}$, and $\mathrm{Zn} 2=0,1050$, and $1750 \mathrm{mg} \cdot \mathrm{L}^{-1} \mathrm{Zn}$, respectively; $1 \mathrm{mg} \cdot \mathrm{L}^{-1}=1 \mathrm{ppm}$. Concentrations are in applied foliar sprays

${ }^{x}$ Within columns, means followed by the same letter are not significantly different by Duncan's multiple range test at $P \leq 0.05$.

$* *, * *$ Significant at $P \leq 0.001$ or 0.0001 , respectively.

pollen production. Optimal B concentrations for application to nut trees have been variously reported as $300 \mathrm{mg} \cdot \mathrm{L}^{-1}$ in hazelnut (Serdar et al., 2005; Silva et al., 2003), $490 \mathrm{mg} \cdot \mathrm{L}^{-1}$ in almond (Nyomora et al., 1997), and $756 \mathrm{mg} \cdot \mathrm{L}^{-1}$ in pistachio [Pistacia vera (Brown et al., 1995b)]. Here, we observed maximal yield and quality parameters with a B application between 174 and $348 \mathrm{mg} \cdot \mathrm{L}^{-1}$, which is consistent with prior results in most fruit and nut trees, though lower than the optimum suggested for pistachio (Brown et al., 1995b).

The benefits of foliar B on yield in walnut can be partially explained by an increase in pollen germination rates. Boron applied at $174 \mathrm{mg} \cdot \mathrm{L}^{-1}$ increased pollen germination at all rates of applied $\mathrm{Zn}$, while foliar $\mathrm{Zn}$ applications were only effective when applied at $1050 \mathrm{mg} \cdot \mathrm{L}^{-1}$ in combination with $174 \mathrm{mg} \cdot \mathrm{L}^{-1} \mathrm{~B}$. Application of $\mathrm{Zn}$ in the absence of $\mathrm{B}$ was ineffective at increasing pollen germination.

\section{Conclusion}

The results provided here confirm that in a walnut orchard with low concentration of available $\mathrm{Zn}$ and $\mathrm{B}$ in soil and leaves, foliar application of $\mathrm{B}$ and $\mathrm{Zn}$ at $174 \mathrm{mg} \cdot \mathrm{L}^{-1} \mathrm{~B}$ and 1050 $\mathrm{mg} \cdot \mathrm{L}^{-1} \mathrm{Zn}$ resulted in a consistent improvement in vegetative growth and reproductive performance of trees. The results also verify observations made in numerous tree species that concentrations of $150-400 \mathrm{mg} \cdot \mathrm{L}^{-1} \mathrm{~B}$ and 1000 $2000 \mathrm{mg} \cdot \mathrm{L}^{-1} \mathrm{Zn}$ are optimal for foliar application of these elements. This study also suggests that combined application of $\mathrm{B}$ and $\mathrm{Zn}$ are synergistic.

\section{Literature cited}

Brown, P.H., L. Ferguson, and G. Picchioni. 1995a. Boron boosts pistachio yields. Fluid J. 4:11-13.

Brown, P.H., Q. Zhang, and J. Grant. 1995b. Improving walnut zinc nutritional status by foliar spray. Walnut Res. Rpt., Walnut Mktg. Board, Modesto, CA.

Brown, P.H., S. Perica, L. Hendricks, K. Kelley, J. Grant, S. Sibbett, and H. Hu. 1999. Foliar boron application to decrease PFA, increase fruit set and yield in walnut. Walnut Res. Rpt., Walnut Mktg. Board, Modesto, CA.

Evenhuis, B. and W. De-Waard. 1980. Principles and practices in plant analysis. United Nations Food Agr. Organization (FAO). Soil Bul. 38:152-163.

Hafez, O.M. and I.M. El-Metwally. 2007. Efficiency of zinc and potassium sprays alone or in combination with some weed control treatments on weeds growth, yield and fruit quality of 'Washington Navel' orange orchards. J. Appl. Sci. Res. 3:613-621

Kaya, C. and D. Higgs. 2002. Response of tomato (Lycopersicon esculentum) cultivars to foliar application of zinc when grown in sand culture at low zinc. Sci. Hort. 93: 53-64.

Lee, S.H., W.S. Kim, and T.H. Han. 2009. Effects of post-harvest foliar boron and calcium applications on subsequent season's pollen germination and pollen tube growth of pear (Pyrus pyrifolia). Sci. Hort. 122:77-82.

Lieten, P. 2002. Boron deficiency of strawberries grown in substrate culture. Acta Hort. 567:451-454.

Luza, J.M. and V.S. Polito. 1991. Progamy and chalazogamy in walnut (Juglans regia). Bot. Gaz. 152:100-106.

Marschner, H. 1986. Functions of mineral nutrients: Macronutrients, p. 195-267. In: R.J. Haynes (ed.). Mineral nutrition of higher plants. Academic Press, Orlando, FL.

McGranahan, G.H., D.G. Voyiatzis, P.B. Catlin, and V.S. Polito. 1994. High pollen loads can cause pistillate flower abscission in walnut. J. Amer. Soc. Hort. Sci. 119:505-509.

Memon, N.N., M. Qasim, and M.J. Jaskani. 2009. Effect of various corm size on the vegetative, floral and corm yield attributes of gladiolus. Pakistan J. Agr. Sci. 46:13-19.

Momeni, A. 2003. An appraisal of land resources of Iran: A contribution to a project on framework for sustainable agricultural development strategy in Iran under the auspices of FAO. United Nations Food Agr. Organization (FAO) Representation, Tehran, Iran.

Neilsen, G.H., D. Neilsen, E.J. Hogue, and L.C. Herbert. 2004. Zinc and boron nutrition management in fertigated high density apple orchards. Can. J. Plant Sci. 84:823-828.

Nyomora, A.M., S. Nyomora, and P.H. Brown. 1997. Fall foliar application boron increases tissue boron concentration and nut set of almond. J. Amer. Soc. Hort. Sci. 122:405-410.

Ostrowska, A., S. Gawlinski, and Z. Szczubialka. 1991. Metody Analizy i Oceny Wlasciwosci Gleb i Roslin. Instytut Ochrony Srodowiska, Warsaw, Poland.

Rajput, C.B.S., B.P. Singh, and H.P. Mishra. 1976. Effects of foliar application of boron on mango. Sci. Hort. 5:311-313.

Ramos, D.E. 1997. Walnut production manual. Div. Agr. Natural Sci., Univ. California, Oakland, CA. 
Serdar, U., A. Horuz, and T. Demir. 2005. The effects of $\mathrm{B}-\mathrm{Zn}$ fertilization on yield, cluster drop and nut traits in hazelnut. J. Biol. Sci. 5:786-789.

Shrestha, G.K., M.M. Thompson, and T.L. Righetti. 1987. Foliar applied boron increase fruit set in 'Barcelona' hazelnut. J. Amer. Soc. Hort. Sci. $121: 412-416$.

Silva, A.P., E. Rosa, and S.H. Haneklaus. 2003. Influence of foliar boron application on fruit set and yield of hazelnut. J. Plant Nutr. 26:561-569.

Solar, A. and F. Stampar. 2001. Influence of boron and zinc application on flowering and nut set in 'Tonda di Gifoni' hazelnut. Acta Hort. 556:307-309.

Sotomayor, C., H. Silva, and J. Castro. 2000. Effect of boron plus zinc foliar spray on fruit setting of two almond cultivars. Acta Hort. 591:437-440.

Storey, J.B. 2007. Zinc, p. 411-437. In: A.V. Barker and D.J. Pilbeam (eds.).
Handbook of plant nutrition. CRC Press, New York.

Umer, S., S.K. Bansal, P. Imas, and H. Magen. 1999. Effect of foliar fertilization of potassium on yield, quality and nutrient uptake of ground nut. J. Plant Nutr. 22: 1785-1795.

Usenik, V. and F. Stampar. 2002. Effect of application of zinc plus boron on sweet cherry fruit set and yield. Acta Hort. 594:245-249.

Ute, K. and S. Clemens. 2005. Functions and homeostasis of zinc, copper, and nickel in plants. Topics Current Genet. 14: 215-271.

Wang, Q., L. Longdou, W. Xiaoqin, L. Yiqin, and L. Jinxing. 2003. Boron influences pollen germination and pollen tube growth in Picea meyeri. Tree Physiol. 23:345-351.

Wojcik, P. 2007. Vegetative and reproductive responses of apple trees to zinc fertilization under conditions of acid coarse-textured soil. J. Plant Nutr. 30: 1791-1802.

Wojcik, P. and W. Treder. 2006. Effect of drip boron fertigation on yield and fruit quality in a high-density apple orchard. J. Plant Nutr. 29:2199-2213.

Zheng, W., M.M. Pi, and W.D. Liu. 1989. A study on the effects of boron on the carbon metabolism of Ramie. J. Huazhong Agr. Univ. 8:354-360.

Ziaeian, A.H. and M.J. Malakouti. 2001. Effects of $\mathrm{Fe}, \mathrm{Mn}, \mathrm{Zn}$ and $\mathrm{Cu}$ fertilization of wheat in the calcareous of Iran, p. 840841. In: W.J. Horst, M.K. Schenk, A. Bürkert, N. Claassen, H. Flessa, W.B. Frommer, H.E. Goldbach, H.W. Olfs, V. Römheld, B. Sattelmacher, U. Schmidhalter, S. Schubert, N. von Wirén, and L. Wittenmayer (eds.). Plant nutrition: Food security and sustainability of agro-ecosystems through basic and applied research. Kluwer Academic Publisher, Dordrecht, The Netherlands. 